\title{
Peningkatan Hasil Belajar Matematika dengan Model Kooperatif Tipe Make a Match
}

\author{
Endang Agustin Soeprijowati ${ }^{(1)}$ \\ ${ }^{1}$ Guru Sekolah Dasar Degeri 3 Dongko Trenggalek, \\ Email: ${ }^{1}$ endangas@gmail.com \\ DOI: https://doi.org/10.28926/riset_konseptual.v2i2.35
}

\begin{abstract}
ABSTRAK
Penyampaian pembelajaran menggunakan cara-cara klasik, ceramah, guru bersifat teacher centered dan berpatokan pada buku paket sehingga siswa kurang termotivasi, berimplikasi prestasi belajar matematika siswa rendah. Tujuan penelitian memperoleh gambaran obyektif peningkatan hasil belajar matematika. Subjek penelitian adalah siswa kelas VI SDN 3 Dongko Kecamatan Dongko Kabupaten Trenggalek tahun 2016, jumlah siswa 20 anak terdiri dari 9 siswa laki-laki dan 11 siswa perempuan. Teknik dan alat pengumpulan data berupa tes. Metode menggunakan analisis data kualitatif. Data yang diperoleh dianalisis ke dalam bentuk deskripsi. Penelitian menggunakan penelitian tindakan (action research) dua siklus dengan tahap rancangan, kegiatan dan pengamatan, refleksi, dan refisi. Hasil penelitian membuktikan penggunaan model make a match dapat meningkatkan hasil belajar siswa dari rata-rata pada studi awal hanya 58,00, naik menjadi 66,50 pada siklus pertama, dan 76,00 pada siklus kedua, dengan tingkat ketuntasan belajar sebanyak 5 siswa $(25,00)$ pada studi awal, $55,00 \%$ atau 11 siswa pada siklus pertama, serta 18 siswa atau 90,00\% pada siklus kedua dan masih terdapat 2 siswa yang belum tuntas belajarnya atau 10,00, namun secara keseluruhan semua kriteria keberhasilan pembelajaran telah tercapai pada siklus kedua. Penggunaan model make a match dapat meningkatkan hasil belajar siswa kelas VI SDN 3 Dongko Kecamatan Dongko Kabupaten Trenggalek pada pelajaran matematika materi menyederhanakan berbagai bentuk pecahan.
\end{abstract}

Kata kunci: matematika, kooperatif, match a match

\section{PENDAHULUAN}

Guru akan memiliki kompetensi mengajar jika memiliki pemahaman dan penerapan secara praktis. "Metode mengajar merupakan salah satu cara yang dipergunakan guru dalam mengadakan hubungan siswa pada saat berlangsungnya pelajaran. Ketepatan penggunaan metode mengajar sangat bergantung kepada tujuan, isi dan proses belajar mengajar. Dengan memanfaatkan metode yang akurat guru akan mampu mencapai tujuan pengajaran, sebaliknya kegagalan tujuan pengajaran akan terjadi jika guru kurang tepat didalam memilih metode pengajaran selama proses belajar berlangsung." Tujuan pembelajaran Matematika di Sekolah Dasar (SD) adalah "agar siswa dapat menggunakan Matematika dengan pola pikirnya dalam kehidupan sehari-hari dan dalam mempelajari berbagai ilmu pengetahuan secara logis, rasional, kritis, cermat, jujur dan efektif. Dalam dunia pendidikan, Matematika dijadikan sebagai salah satu bidang studi yang menduduki peranan penting. Hal ini ditunjukkan dengan banyaknya jam pelajaran Matematika di sekolah dalam pelaksanaan pendidikan. Sebagai perwujudan pencapaian tujuan pembelajaran Matematika, belajar merupakan proses aktif yang memerlukan dorongan dan bimbingan dalam penguasaan hasil belajar siswa. mencakup tiga elemen yaitu (1) konsep, (2) keteramplian, dan (3) pemecahan masalah". Kenyataan yang ditemui di lapangan pada pelaksanaan observasi awal pada siswa kelas VI SDN 3 Dongko Kecamatan Dongko Kabupaten Trenggalek tempat peneliti melakukan penelitian, ternyata cukup banyak siswa yang menganggap pelajaran matematika salah satu mata pelajaran yang sulit dan membosankan. Ketika mengajar guru juga lebih berpatokan pada buku paket perhalamannya. Hal ini membuat siswa kurang termotivasi. Salah satu faktor yang dapat meningkatkan kemampuan siswa adalah dengan penerapan pendekatan 
pembelajaran di kelas. Agar siswa bisa termotivasi, menyenangi mempelajari matematika dan mempunyai sikap positif terhadap matematika serta dapat meningkatkan kemampuan komunikasi matematiknya, maka diperlukan upaya untuk menciptakan suatu pembelajaran matematika yang menyenangkan siswa dalam belajar.

Salah satu pendekatan yang memungkinkan untuk dilakukan adalah menggunakan pendekatan pemecahan masalah dengan metode make a match. Hasil tes pendahuluan yang dilaksanakan menunjukkan penguasaan siswa terhadap materi tersebut masih sangat rendah. Hal ini dibuktikan hanya 5 siswa atau $(25,00 \%)$ dari jumlah keseluruhan 20 siswa.. Berdasarkan hal tersebut, peneliti meminta bantuan teman sejawat dan kepala sekolah untuk membantu mengidentifikasi kekurangan dari pembelajaran yang sudah dilaksanakan. Secara khusus faktor yang mempengaruhi prestasi belajar siswa adalah: Siswa kurang motivasi dalam belajar, media pembelajaran yang kurang lengkap, penggunaan media pembelajaran yang tidak tepat, siswa kurang memperhatikan penjelasan guru, kepedulian orang tua terhadap anak di rumah kurang. Dalam hal ini metode yang diterapkan adalah metode diskusi. Metode diskusi dipilih dengan pertimbangan dan akan membangkitkan semangat siswa dengan temannya yang merupakan tutor sebaya. Disamping itu siswa akan terbiasa berfikir kritis, kreatif dan mampu berpendapat sehingga dapat meningkatkan pemahamannya. Penerapan metode ini tentunya tidak dapat berdiri sendiri, namun tetap didukung dengan metode yang lain, hanya saja prioritas tetap pada metode diskusi. Sebaliknya pembelajaran tanpa menggunakan metode pembelajaran yang tepat akan mengakibatkan siswa kesulitan memahami konsep yang dipelajari. Sebagai wujud tanggung jawab sebagai guru yang profesional, peneliti merasa terminat untuk melakukan perbaikan pembelajaran agar hasil belajar siswa dapat meningkat. Upaya perbaikan yang peneliti lakukan dengan mengadakan Penelitian Tindakan Kelas (PTK) materi pokok menyederhanakan pecahan dengan model pembelajaran kooperatif tipe make a match di Kelas VI SDN 3 Dongko Kecamatan Dongko Kabupaten Trenggalek Tahun 2015/2016. Sesuai dengan permasalahan penelitian, tujuan penelitian tindakan kelas ini ialah mengetahui gambaran obyektif mengenai peningkatan hasil belajar matematika materi pokok menyederhanakan pecahan dengan model pembelajaran kooperatif tipe make a match pada siswa kelas VI SDN 3 Dongko Kecamatan Dongko Semester II Tahun Pelajaran 2015/2016.

\section{METODE}

Metode yang digunakan dalam penelitian ini menggunakan Penelitian Tindakan Kelas (PTK) yang merupakan suatu penelitian tindakan dalam bidang pendidikan yang bertujuan untuk memperbaiki atau meningkatkan mutu pembelajaran di kelas. Penelitian Tindakan Kelas merupakan suatu bentuk penelitian yang bersifat reflektif dengan melakukan tindakan-tindakan tertentu agar dapat memperbaiki atau meningkatkan praktek pembelajaran di kelas secara proposional. Subjek penelitian ini dilaksanakan di Kelas VI SDN 3 Dongko Kecamatan Dongko Kabupaten Trenggalek, dengan jumlah siswa sebanyak 20 anak terdiri dari 9 siswa laki-laki dan 11 siswa perempuan. Instrumen pengumpulan data instrumen data yang dilakukan dalam penelitian tindakan kelas ini adalah tes. Tes adalah alat pengumpul informasi mengenai hasil belajar yang berupa pertanyaan atau kumpulan pertanyaan.

\section{Rancangan Penelitian}

Penelitian yang dilaksanakan ini menggunakan Penelitian Tindakan Kelas (PTK) sesuai dengan jenis penelitian yang dipilih, yaitu penelitian tindakan, maka penelitian ini menggunakan model penelitian tindakan dari Kemmis dan Taggart (Sugiarti, 1997:6), yaitu berbentuk spiral dari sklus yang satu ke siklus yang berikutnya. Setiap siklus meliputi planning (rencana), action (tindakan), observation (pengamatan), dan reflection (refleksi). Langkah pada siklus berikutnya adalah perncanaan yang sudah direvisi, tindakan, pengamatan, dan refleksi. Sebelum masuk pada siklus 1 
dilakukan tindakan pendahuluan yang berupa identifikasi permasalahan. Menurut Wardani, dkk. (2004:2.4) bahwa langkah-langkah Penelitian Tindakan Kelas (PTK) terdiri dari empat langkah yaitu merencanakan, melakukan tindakan, melakukan pengamatan, dan melakukan refleksi. Menurut Ruseffendi (1991:23) dalam melaksanakan PTK ada beberapa langkah-langkah terperinci yang seharusnya diikuti oleh peneliti/guru, yaitu: (a) perencanaan, (b) implementasi tindakan, (c) observasi, dan (d) refleksi. Penjelasan secara rinci dapat dilihat pada uraian di bawah ini:

\section{Perencanaan}

Penentuan perencanaan dapat dibagi menjadi dua jenis, yaitu perencanaan umum dan perencanaan khusus. Hal-hal yang direncanakan di antaranya terkait dengan pendekatan pembelajaran, metode pembelajaran, teknik atau strategi pembelajaran, media dan materi pembelajaran, dan sebagainya. Perencanaan dalam hal ini kurang lebih hampir sama dengan apabila kita menyiapkan suatu kegiatan belajar mengajar. Biasanya perencanaan dimasukkan ke dalam Rencana Pelaksanaan Pembelajaran (RPP) dan juga dapat dimasukkan ke dalam silabus mata pelajaran yang bersangkutan.

\section{Pelaksanaan}

Implementasi tindakan pada prinsipnya merupakan realisasi dari suatu tindakan yang sudah direncanakan sebelumnya. Strategi apa yang digunakan, materi apa yang diajarkan atau dibahas dan sebagainya. PTK bersifat emansipatoris dan membebaskan (Liberating), karena mendorong kebebasan guru dalam berpikir dan berargumentasi dalam bereksperimen, meneliti, dan mengambil keputusan atau judgment. Pekerjaan utama seorang guru adalah mengajar, sehingga dalam melakukan PTK seyogyanya tidak berpengaruh pada komitmennya sebagai pengajar. Adanya kebebasan dalam PTK di sekolah justru harus menyulut guru melakukan inovasi dalam proses pembelajarannya di kelas dalam rangka meningkatkan kualitas pendidikan.

\section{Pengamatan}

Kegiatan observasi dilakukan bersamaan dengan pelaksanaan tindakan. Data yang dikumpulkan pada tahap ini berisi tentang pelaksanaan tindakan dan rencana yang sudah dibuat, serta dampaknya terhadap proses dan hasil intruksional yang dikumpulkan dengan alat bantu instrumen pengamatan yang dikembangkan oleh peneliti. Pada tahap ini perlu mempertimbangkan penggunaan beberapa jenis instrumen ukur penelitian guna kepentingan triangulasi data. Dalam melaksanakan observasi dan evaluasi, guru tidak harus bekerja sendiri. Dalam tahap observasi ini guru bisa dibantu oleh pengamat dari luar (sejawat atau pakar). Dengan kehadiran observer/teman sejawat dalam penelitian ini, PTK yang dilaksanakan menjadi bersifat kolaboratif. Hanya saja pengamat luar tidak boleh terlibat terlalu dalam dan mengintervensi terhadap pengambilan keputusan tindakan yang dilakukan oleh peneliti. Terdapat empat metode observasi, yaitu: observasi terbuka; observasi terfokus; observasi terstruktur dan dan observasi sistematis. Beberapa prinsip yang harus dipenuhi dalam observasi diantaranya a) ada perencanaan antara dosen/guru dengan pengamat, (b) fokus observasi harus ditetapkan bersama; (c) dosen/guru dan pengamat membangun kriteria bersama; (d) pengamat memiliki keterampilan mengamati; dan (e) balikan hasil pengamatan diberikan dengan segera. Adapun keterampilan yang harus dimiliki pengamat di antaranya: (a) menghindari kecenderungan untuk membuat penafsiran; (b) adanya keterlibatan keterampilan antar pribadi; (c) merencanakan skedul aktifitas kelas; (d) umpan balik tidak lebih dari 24 jam; (d) catatan harus teliti dan sistematis. 


\section{Refleksi}

Refleksi, mengetahui dampak pemberian teknik modeling dan mengetahui apakah dalam pelaksanaan tindakan peneliti telah menggunakan metode modeling dengan tepat, maka selama proses pembelajaran berlangsung, aktivitas peneliti diamati oleh satu orang sebagai observer. Istilah "refleksi" dari kata bahasa Inggris reflection, diterjemahkan dalam bahasa Indonesia pemantulan. Kegiatan refleksi ini sebetulnya lebih tepat dikenakan ketika guru pelaksana sudah selesai melakukan tindakan, kemudian berhadapan dengan peneliti untuk mendiskusikan implementasi rancangan tindakan. Inilah inti dari penelitian tindakan, yaitu ketika guru pelaku tindakan mengatakan kepada peneliti pengamat tentang hal-hal yang dirasakan sudah berjalan baik dan bagian mana yang belum. Apabila guru pelaksana juga berstatus sebagai pengamat, maka refleksi dilakukan terhadap diri sendiri. Dengan kata lain guru tersebut melihat dirinya kembali, melakukan "dialog" untuk menemukan hal-hal yang sudah dirasakan memuaskan hati karena sudah sesuai dengan rancangan dan mengenali hal-hal yang masih perlu diperbaiki. Dalam hal seperti ini maka guru melakukan "self evaluation" yang diharapkan dilakukan secara obyektif. Untuk menjaga obyektifitas tersebut seringkali hasil refleksi ini diperiksa ulang atau divalidasi oleh orang lain, misalnya guru/teman sejawat yang diminta mengamati, ketua jurusan, kepala sekolah atau nara sumber yang menguasai bidang tersebut. Jadi pada intinya kegiatan refleksi adalah kegiatan evaluasi, analisis, pemaknaan, penjelasan, penyimpulan dan identifikasi tindak lanjut dalam perencanaan siklus selanjutnya.

\section{Teknik Pengumpulan Data}

Adapun teknik pengumpulan data dilakukan dengan tes dimaksudkan untuk mengetahui kemampuan peningkatan kemampuan siswa setelah menggunakan model make a match. Tes yang digunakan pada penelitian ini yaitu tes tulis berbentuk isian.

\section{Teknik Analisa Data}

Metode analisis data dalam penelitian ini menggunakan analisis data kualitatif. Data yang diperoleh dari hasil observasi, dokumentasi dan portofolio dianalisis ke dalam bentuk deskripsi. Analisis data penelitian kualitatif bersifat interaktif berlangsung. Teknik yang digunakan fleksibel, tergantung pada strategi yang digunakan dan data yang telah diperoleh (Sukmadinata, 2005:114). Tahap pertama menggunakan teknik analisis deskriptif. Tahap kedua dengan membandingkan antara hasil rekapitulasi nilai siklus I dengan rekapitulasi siklus II. Dalam hal ini peneliti menggunakan analisis data kualitatif yang berkesinambungan yang mencakup kegiatan-kegiatan sebagaimana dijelaskan oleh Anggoro (2008:18). Evaluasi kualitatif tentang validitas atau kepercayaan data yang terus menerus. Data yang dikumpulkan oleh guru yang berperan sebagai peneliti merupakan data kualitatif dan dianalisis secara kualitatif deskriptif. Hasil belajar siswa dianalisis secara kuantitaif. Menurut Arikunto (2011:45) analisis data dimaksudkan untuk mengetahui ketuntasan belajar siswa dalam kegiatan belajar mengajar.

HASIL

Hasil pelaksanaan pembelajaran yang dilakukan di kelas VI SDN 3 Dongko Kecamatan Dongko Kabupaten Trenggalek pada pembelajaran matematika menggunakan materi menyederhanakan bentuk pecahan dalam dua siklus pelaksanaan pembelajaran melalui metode make a match menunjukkan hasil yang maksimal. Kenyataan yang ditemui di lapangan pada pelaksanaan observasi awal tempat peneliti melakukan penelitian, ternyata cukup banyak siswa yang menganggap pelajaran matematika merupakan salah satu mata pelajaran yang sulit dan membosankan. Hal itu disebabkan karena dalam menyampaikan materi, guru masih menggunakan cara-cara klasik yaitu menggunakan metode-metode lama, seperti ceramah, kegiatan guru lebih mendominasi (teacher centered) dibanding dengan siswa. Ketika mengajar guru juga lebih berpatokan pada buku paket perhalamannya. 
Hal ini membuat siswa kurang termotivasi, kurang aktif dan kurang menyenangi pelajaran matematika, sehingga prestasi belajar matematika siswa rendah. Dari permasalahan yang ada, penggunaan metode pembelajaran merupakan prioritas yang utama yang harus diperbaiki. Karena penerapan metode yang tepat akan berdampak pada hasil belajar pada siswa. Dalam hal ini metode yang diterapkan adalah metode diskusi. Metode diskusi dipilih dengan pertimbangan dan akan membangkitkan semangat siswa belajar dengan temannya yang merupakan tutor sebaya. Disamping itu siswa akan terbiasa berfikir kritis, kreatif dan mampu berpendapat sehingga dapat meningkatkan pemahamannya. Dengan meningkatnya pemahaman maka hasil belajarnya juga meningkat. Penerapan metode ini tentunya tidak dapat berdiri sendiri, namun tetap didukung dengan metode yang lain, hanya saja prioritas tetap pada metode diskusi. Sebaliknya pembelajaran tanpa menggunakan metode pembelajaran yang tepat berdampak pada pemahaman siswa kesulitan memahami konsep yang dipelajari. Akibatnya hasil belajar siswa mengecewakan. Oleh karena itu dalam pembelajaran ini menggunakan metode diskusi untuk meningkatkan keaktivan dan hasil belajar siswa. Melihat hasil-hasil analisis data studi awal maka dapat disimpulkan terjadi permasalahan pembelajaran yang memerlukan penanganan serius. Upaya yang dilakukan oleh peneliti selaku guru di kelas VI tersebut adalah dengan melaksanakan kegiatan penelitian tindakan kelas menggunakan model pembelajaran kooperatif tipe make a match. Berdasarkan rumusan masalah yang telah dipaparkan di atas, maka peneliti bekerja sama dengan observer untuk membuat rencana pelaksanaan pembelajaran materi menyederhanakan bentuk pecahan, mempersiapkan bahan ajar atau buku-buku yang relevan dengan materi pelajaran, mempersiapkan alat bantu mengajar yang diperlukan, mempersiapkan lembar kerja siswa, mempersiapkan lembar evaluasi. Pada tahap pengamatan mengenai pembelajaran, penjelasan yang diberikan masih bersifat abstrak sehingga siswa masih kesulitan memahami penjelasan yang diberikan guru tentang materi pembelajaran mengurutkan bilangan pecahan dengan model pembelajaraan cooperatif tipe make a match.

\section{PEMBAHASAN}

Pada siklus pertama, dengan menggunakan metode make a match, belajar siswa kurang memuaskan, karena dari observasi yang dilakukan menunjukkan bahwa belum semua siswa aktif dalam kegiatan pembelajaran, hasil Belajar meningkat cukup baik, yaitu dari nilai rata-rata hasil belajar sebesar 58,00 pada studi awal, menjadi 66,50 pada siklus pertama, sedangkan tingkat ketuntasan belajar baru mencapai angka 11 siswa atau 55,00\%. Melihat hasil di atas maka peneliti bersama-sama dengan observer sepakat untuk melaksanakan pelaksanaan pembelajaran pada siklus II dengan harapan pada siklus II rata-rata hasil belajar siswa dapat mencapai perolehan di atas KKM sebesar 68,00, dan ketuntasan belajar minimal $85 \%$ dari jumlah siswa sesuai dengan kriteria keberhasilan yang telah ditetapkan. Dari hasil diskusi dengan teman sejawat, maka disimpulkan bahwa proses pelaksanaan pembelajaran pada siklus kedua perlu ditanggulangi dengan menjelaskan mengurutkan pecahan dengan model pembelajaran make a match.

Selanjutnya dengan menggunakan metode make a match, hampir seluruh siswa dapat belajar tuntas. Peningkatan hasil belajar meningkat cukup baik, yaitu dari nilai rata-rata hasil belajar sebesar 66,50 pada siklus pertama, menjadi 76,00 pada siklus kedua, sedangkan tingkat ketuntasan belajar mencapai angka 18 siswa atau $90,00 \%$ atau dan masih terdapat dua siswa yang belum tuntas belajarnya atau sebesar $10,00 \%$. Melihat hasil di atas maka peneliti bersama-sama dengan observer menyimpulkan bahwa hasil tes hasil belajar menunjukkan hasil 76,00. Hal ini menunjukkan bahwa tes hasil belajar sudah memenuhi kriteria keberhasilan karena hasil belajar berada di atas angka kriteria minimal ketuntasan (KKM) sebesar 68 dan siswa tuntas menunjukkan angka 18 siswa atau $90,00 \%$ sehingga proses pelaksanaan pembelajaran dinyatakan berhasil dan tuntas pada pelaksanaan siklus II karena sudah berada di atas kriteria keberhasilan sebesar $85 \%$. Dari hasil analisis data yang 
dilakukan pada setiap siklus pelaksanaan tindakan pada penelitian tindakan kelas ini dapat disimpulkan bahwa ketuntasan belajar siswa yang terjadi pada setiap siklus menunjukkan kenaikan yang cukup baik. Hal tersebut didukung pula oleh kenaikan hasil belajar siswa dari rata-rata pada studi awal hanya 58,00, naik menjadi 66,50 pada siklus pertama, dan 76,00 pada siklus kedua, dengan tingkat ketuntasan belajar sebanyak 5 siswa (25,00\%) pada studi awal, 55,00\% atau 11 siswa pada siklus pertama, serta 18 siswa atau 90,00\% pada siklus kedua dan masih terdapat dua siswa yang belum tuntas belajarnya atau $10 \%$, namun secara keseluruhan semua kriteria keberhasilan pembelajaran telah tercapai pada siklus kedua. Setelah melakukan analisa terhadap data yang peroleh dari dua siklus yang dilaksanakan maka dapat dapat disimpulkan bahwa penggunaan metode make a match pada pembelajaran matematika materi menyederhanakan bentuk pecahan menunjukkan peningkatan yang signifikan terhadap hasil proses pembelajaran.

\section{KESIMPULAN}

Didasarkan temuan dan hasil yang diperoleh dapat ditarik kesimpulan. Penggunaan model pembelajaran kooperatif tipe make a match dapat meningkatkan hasil belajar siswa dari rata-rata pada studi awal hanya 58,00, naik menjadi 66,50 pada siklus pertama, dan 76,00 pada siklus kedua, dengan tingkat ketuntasan belajar sebanyak 5 siswa (25,00\%) pada studi awal, 55,00\% atau 11 siswa pada siklus pertama, serta 18 siswa atau 90,00\% pada siklus kedua dan masih terdapat dua siswa yang belum tuntas belajarnya atau $10,00 \%$, namun secara keseluruhan semua kriteria keberhasilan pembelajaran telah tercapai pada siklus kedua.

\section{SARAN}

Mengingat pembelajaran dilakukan di kelas $\mathrm{VI}$, dengan mata pelajaran Matematika, dimana sering terhambat pada kesiapan siswa dan hasil belajar yang tidak tetap terhadap pelajaran tersebut, maka seyogyanya model pembelajaran yang mengandung nilai peningkatan hasil belajar sangat perlu diperlukan, khususnya suasana pembelajaran yang menyenangkan, hal ini karena aspek psikologis anak yang senang belajar atau bekerja dalam kelompok dan senang melakukan atau memperagakan sesuatu secara langsung. Tidak kalah pentingnya dalam melaksanakan perbaikan pembelajaran matematika, senantiasa diciptakan komunikasi harmonis dan humoris antara guru dan siswa agar kesan matematika bukan lagi sebagai mata pelajaran yang menakutkan.

\section{DAFTAR RUJUKAN}

Anggoro, M. Toha. 2008. Metode Penelitian. Jakarta: Universitas. Terbuka Arikunto, S. 2002. Dasar-dasar Evaluasi Pendidikan. Jakarta: Bumi Aksara Arikunto, S. 2011. Penelitian Tindakan Kelas. Jakarta : Bumi Aksara.

Depdiknas. 2004. Undang-Undang Republik Indonesia No. 20 Tahun 2003 tentang

Sistem Pendidikan Nasional. Jakarta: Depdiknas.

Depdikbud. 1997. Kamus Besar Bahasa Indonesia. Jakarta: Balai Pustaka.

Hudojo, Herman. 1988. Mengajar Belajar Matematika. Jakarta: Dirjen Dikti PPLPTK.

Heruman. 2007. Model Pembelajaran Matematika di Sekolah Dasar. Bandung: Penerbit PT Remaja

Kennedy. 1994. Guiding Childrens Learning of Mathematics. California : Wadsworth Publishing Company.

Lisnawaty, dkk. 1993. Metode Mengajar Matematika Jilid I. Jakarta : Rineka Cipta.

Lorna Curran. 1994. Metode Pembelajaran Make a Match. Jakarta: Pustaka. Belajar

Nana Sudjana, 2010. Dasar-Dasar Proses Belajar Mengajar. Bandung: Sinar Baru Algensindo

Nana Sudjana, 2004. Dasar-Dasar Proses Belajar Mengajar. Bandung: Sinar Baru Algensindo

Nana Syaodih Sukmadinata. 2005. Meode Penelitian Pendidikan. Bandung; Remaja. 
Ruseffendi, ET. 1991. Pengantar Kepada Membantu Guru Mengembangkan Kompetensinya dalam Pengajaran Matematika untuk Meningkatkan CBSA. Bandung. Tarsito

Amin Suyitno. 2004. Dasar-Dasar dan Proses Pembelajaran Matematika I. Semarang: UNNES

Simanjutak, Lisnawaty. 1993. Metode Mengajar Matematika, Jakarta: PT Rineka Cipta. Sujono (1988). Matematika. Dirjen Dikti : Jakarta.

Wardani,dkk. 2004. Penelitian Tindakan kelas. Jakarta: Pusat Penerbitan Universitas Terbuka

Zubaidi. 2011. Desain Pendidikan Karakter. Jakarta : Kencana Prenada Media. 